\title{
Kyrios and despotes: addresses to deities and religious experiences
}

\begin{abstract}
Addresses to deities as kyrios/a and despotes ("master" or "lord") top a list that encompasses a rich lexicon of divine rulership. My study tackles two combined issues raised by these two onomastic attributes: (1) do they betray mainly the memory of a more peculiar and closer religious experience of deities than do other addresses? (2) to what extent do the two terms express a prominent status of the experienced deities leading towards a "henotheistic" interpretation, as usually conceptualized by modern research? The collection and study of epigraphic testimonies invited me to distance my conclusions from both the three features generally recognized when deities are praised thus (slave's submission, oriental flavor and henotheism) and current interpretations that treat the two terms as synonymous, as if expressing the same kind of experience of the deity. In the three geographical - thus cultural - areas under scrutiny, where these ritual epithets are the more numerous (the Levant, Thracia and its surroundings, and Egypt), any divine power is implicitly kyrios in his/her own sanctuary. Despotes might be a better candidate for advocating an evolution towards a hierarchical/henotheistic conception of the pantheon and its expression in specific religious experiences.
\end{abstract}

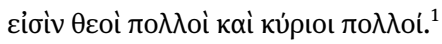

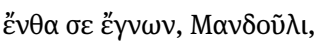

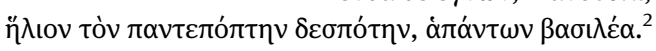

In the first Letter to the Corinthians, quoted above in excerpt, Paul noted the multiplicity of gods and kyrioi in order to distance his faith, and his God, from the conception of a plural divine world. For approaching both the topics of the structure and functioning of polytheisms throughout the kaleidoscopic aspects of divine

1 Paul, Ep. Cor. I, 8, 5: "there are many gods and many lords". I thank Dan Dana for our discussion on Thracia and its surroundings.

2 Bernand 1969, no. 166, 1l. 7-8, at Talmis (Kalabsha, Nubia), 1st-3rd century CE (= SB 4127): "Then I knew you, Mandoulis, the sun, all-seeing Lord, Master of everything”.

Ә Open Access. (C) 2020 Nicole Belayche, published by De Gruyter. (cc) BY-NC-ND This work is licensed under a Creative Commons Attribution-NonCommercial-NoDerivatives 4.0 International License.

https://doi.org/10.1515/9783110557596-006 
powers / 'puissances' (J.-P. Vernant), ${ }^{3}$ and the kinds and deepness of religious experiences, addresses to deities - the more so the epicleseis (i.e. ritual epithets) that deities are given in epigraphic dedications - offer an avenue. ${ }^{4}$ Considering the theme under scrutiny, "experiencing the religious", I choose to focus on this corpus of written evidence because literary texts (novels and poetry mainly) narrate religious experiences through imaginative discourses, even when they rely or could rely on actual facts - thus endless discussions on the historical value of some texts like Apuleius' Metamorphoses XI. Epigraphy also has its discursive rules and strategies, notwithstanding stereotyped formulas; yet the fact that the author of an inscription usually speaks in the first person betrays a different stage and network of mediation, among which that of the temple authorities where the inscription is set up. Moreover, comparing lists of Latin and Greek epithets in literary evidence (Bruchmann 1893-1902; Santoro 1974; Ronchi 1974-1977) and indexes of epigraphic publications, demonstrates that the range of epithets is far larger in the first category. ${ }^{5}$ Artistic creation left more freedom, imagination and space for inventiveness than cultic communication, as the prose writer Aelius Aristides complained. ${ }^{6}$

In historiography, some of these ritual epithets are considered as reflecting testimony both of more intense or intimate experiences of the gods, and a state of submission of the worshipper that would be characteristic of an 'Eastern religiosity' (Pleket 1981, 176). Addresses to deities as kyrios/a and despotes ("master" or "lord") top a list that encompasses a rich lexicon of divine rulership. My study tackles two combined issues raised by these two epithets: (1) investigating whether they betray mainly the memory of a more peculiar and closer religious experience of deities than do other dedications; and (2) appreciating to what extent the two terms express a prominent status of the experienced deities leading towards a "henotheistic" interpretation, as usually conceptualized by modern research. Such an inquiry opens towards a large

3 Vernant 1985, 362: "Les dieux helléniques sont des Puissances, non des personnes”. Cf. Bonnet, Belayche et al. 2017.

4 E.g. out of a long bibliography, Belayche et al. 2005. The research group "Mapping polytheisms" headed by Corinne Bonnet (Toulouse, FR) proposes now the syntagma "attribut onomastique”, Bonnet et al. 2018.

5 See for instance in Latin texts the numerous portraits of any deity as "potens" (Aesculapius, Amor, Apollon, Ceres, Dis, Fortuna, Juno, Jupiter, Lar, Liber, Mars, Neptune, Pan, Priape, Rome, Silvanus, Terra, Venus, Vesta), with or without their sphere of power (Armipotens, Ignipotens, Salsipotens, etc.), while potens is rare in epigraphic dedications and restricted to a few deities (Diana: CIL 3, 1418 and 11, 3198).

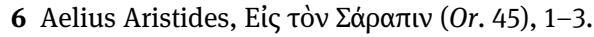


horizon in history of religions, in so far as kyrios/a and despotes are not neutral terms as we shall see.

The collection and study of epigraphic testimonies invites me to distance my conclusions from current interpretations that treat the two terms as synonymous, as if expressing the same kind of experience of the deity. Actually, their uses reveal different religious connotations within the three geographical - thus cultural areas where these ritual epithets are the more numerous: the Levant, Thracia and its surroundings, and Egypt. ${ }^{7}$ At the very least they display significant nuances that will be underlined. Even in the Near East - where kyrios/a has a large range of meanings, yet with little clear evidence of direct experience of the divine (as in epiphanies for instance), and where despotes is rarely attested before Christian testimonies (from the 5th century onwards) ${ }^{8}$ - for the most part, kyrios/a designates an authoritative status of the deity within a sanctuary. In the three areas under scrutiny, increasing attestations of the two terms during the imperial period accords with the social trend towards glorification of powerful figures, either divine or human, that flourished within the contemporary context of civic competitions (see e.g. Belayche 2010, with previous bibliography). Viewed from this social history perspective, kyrios participates in an evolution that coined the religious language in the Roman Eastern Mediterranean, putting emphasis on a political lexicon ("épithètes de puissance" in French, "Machtepitheta" in German) ${ }^{9}$ in line with competitive concerns in civic societies of the time. ${ }^{10}$ Voicing a masterly status within a community of gods and humans, addressing a deity as kyrios does not say a lot about a theological conception of the "société des dieux" (J.P. Vernant) itself. Despotes, in contrast, is more frequently used when worshippers experience the divine personally, through oracles, dreams, or other similar specific experiences, as Egyptian testimonies will demonstrate clearly.

After some necessary historiographical reminders, I shall first examine Levantine evidence, since the prevalent scholarly position on the term kyrios stresses both an "oriental connection" and submission to deities. I shall then pass to the two other areas rich with attestations, searching for eventual differences. The Thracian repertoire of kyrios/a will demonstrate a literal use of the term for identifying divine powers - as masters of the (cult) place. Finally, Egyptian documents will show a clear distinction between kyrios and despotes in relation to worshippers' religious experiences.

7 The demonstration will not refer to the exhaustive repertoire of attestations for reasons of space.

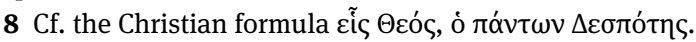

9 Cf. Chaniotis and Chiai 2007, 121.

10 For acclamatory epithets, Chaniotis 2009, 208-213 and Chaniotis 2010, 130-131 n. 80. 


\section{Kyrios according to the "orthodox" thesis (H.W. Pleket)}

These historiographical observations are intended to draw attention (though briefly) to a possible hermeneutic bias arising from the Jewish use of Kyrios as one of the Greek designations of the Jewish God in the Septuagint ${ }^{11}$ (and then its Christian application to Jesus Christ), ${ }^{12}$ when interpretations of epigraphic addresses to gods/goddesses as kyrios/ $a$ are at stake. There is not much evidence to single out the term in traditional, Greek and Roman, religions. Few testimonies come from ancient Greece. ${ }^{13}$ Classicists list kyrios within a large category of epithets of power and sovereignty: "master of" the house, and then of the empire, ${ }^{14}$ "the one who has authority over" (e.g. the parthenoi), "lord" or "monarch" like dominus in Latin (Chantraine 2009 [1968-1980], 578-579). Actually, Zeus can be kyrios in archaic and classical Greek poetry and drama, ${ }^{15}$ as are other deities. Yet Greek gods' sovereignty is rather termed with other words in literary or epigraphic evidence (like the oracular tablets from Dodona): potnia, anax, ${ }^{16}$ basileus, despotes (generally only in specific contexts), ${ }^{17}$ despoina. Starting from the basic, literal meaning, historians of religions rightly stress the vertical relationship between gods and men as expressed in the ritual uses of kyrios.

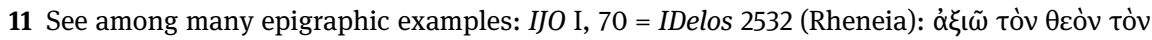

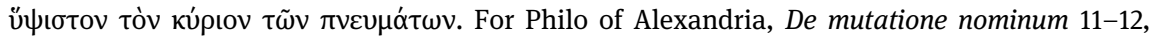
God is Kyrios, but this is not a personal name. The reference book is Baudissin 1926-1929, discussed by Cerfaux 1931 for the shift from the Tetragrammaton to "le Seigneur qui s'est attaché son peuple". On the question of the use of Kyrios or the Tetragrammaton in the Septuaginta, Pietersma 1984 and Harl 1986, 51-52.

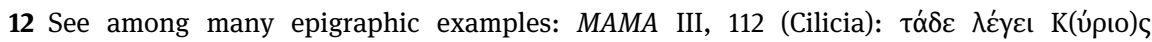

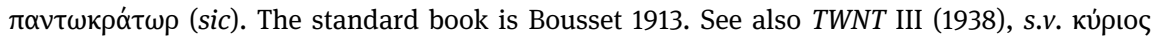
(W. Foerster) and SDB 5 (1957), s.v. "Kyrios” (L. Cerfaux), col. 199-228; Nock 1928 [1972], 74-77. 13 Thus this chronological precision by Versnel 2011, 304, when defining henotheism: "Though most of the elements analyzed above [i.e. the nine characteristics of henotheism] can already be found sporadically in earlier periods, their amalgamation into one structural complex is specifically characteristic of the religious mentality we have been discussing."

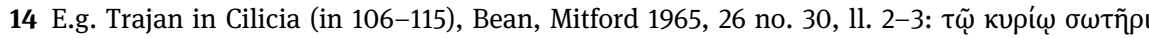

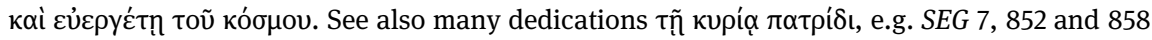
(Gerasa, 2nd century).

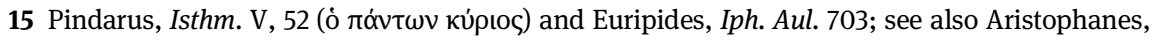
Plut. 748.

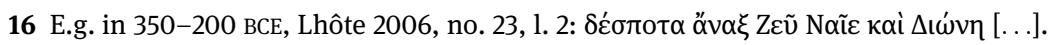

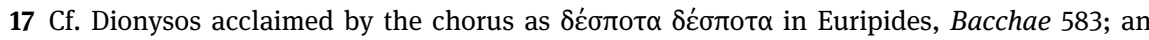
Attic defixio (imprecation) addressed to the masters of the underworld, IG III, App. 94: $[\tilde{\omega}]$

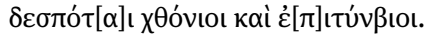


Yet, upon interpretation, the dominant trend is that kyrios would betray a political (monarchic) and "oriental" religious conception, which spread in the Eastern Mediterranean from the Hellenistic period onwards.

I shall limit the review to two great scholars who marked important steps: from Arthur Darby Nock in 1925 to Hans Pleket in 1981 (for Latin evidence, Veyne 1986). Their interpretations of kyrios put emphasis on religious behaviors presented as obeying divine orders (after formulas like "kata suntagma / onar / epitagen", etc.) or describing the worshippers as slaves of the deities - thus its examination in the magnum opus of Franz Bömer on the religion of the slaves. ${ }^{18}$ In Nock's words in 1925:

That conception of the gods as absolute rulers [...] becomes prominent in Hellenistic times and finds expression in such titles as kyrios, despotès, tyrannos. The gods were assimilated to the absolute monarchs of the East.

[Nock, 1925 (1972), 47]

Three years later, the great master of Harvard singled out a turning point in the Hellenistic period after the classical, literal use of kyrios:

the nuance of Kyrios depends on the person or god to whom it is applied; it can be a mere courtesy title, like "Master" in English. In Christianity, just as in many Hellenistic cults, it implies a belief in the divine overruling of the individual, who receives commands from on high.

[Nock 1928 (1972), 87; my emphasis]

In 1928 already, A.D. Nock envisioned my two present issues (a status designation and a personal relationship), yet with the hermeneutic model of his time, asserting a praeparatio to Christianity by the Hellenistic, and then Roman, reli-

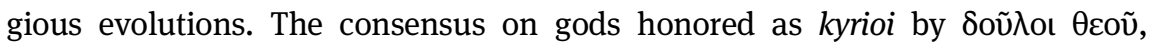
according to an "oriental" conception, was revisited by Hans Pleket in 1981 (esp. 174-178). Though recalling documents going back to classical Greece, he reasserted the oriental influence during the post-Classical period, mirroring monarchic systems:

this dependency is strengthened and disseminated in the Hellenistic-Roman period under Oriental influence and in connection with the rise of autocratic political systems. ${ }^{19}$

[Pleket 1981, 155]

18 Bömer 1961, esp. 193-214. Yet in the sanctuary of the Mother of Gods at Leukopetra

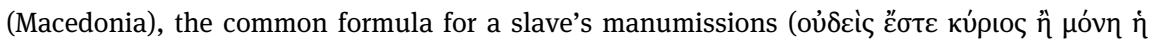
Өcóc, I Leukopétra, no. 90 in 238-239) does not transform the newly free man into a sacred slave. He gets his freedom while entering into the patronage of the Mother and becoming her cliens, thus with no other possible master (kyrios/dominus).

19 Pleket 1981, 179 considers that the social structure offered a favorable field to this "ideology of power"; for a discussion of the dialectic between freedom and tyranny as a conscious 
Actually one rarely finds the entry kyrios in indices of books on Greek and Roman religions, even when religion in the Hellenistic Near East is under discussion (e.g. Bonnet 2015). On the other hand, all dictionaries or lexica of the Bible or the New Testament (see above n. 12) have the item, ${ }^{20}$ when they refer to the previous use of the term (the Pentateuch was translated in the 3rd century BCE). They all argue for what Pleket calls the "orthodox" version, after recalling the Semitic words translated by kyrios - Ba'al/Ba'alat (Lord, Dame) and Adon (Master). ${ }^{21}$ Following this interpretation, kyrios is connected to an "oriental” context or influence (whatever ambiguities vested with the term, Belayche 2000) characterized by the two aforementioned interwoven features: an absolute authority of the divine power who, consequently, rules over worshippers enslaved to it, in contrast to the libertas of the traditional, contractual relationship with the gods. A third feature also rests on such a basis: addressing a deity as kyrios accords with the "henotheistic" conception of pagan theology during the imperial period. ${ }^{22}$

Evidence called to support the argument is far from displaying the advocated features - to say nothing of the current debate on the existence of divine rulership in Greek classical, polytheistic thinking (recent, comprehensive analysis in Versnel 2011 and 2017). First, the collection of epigraphic evidence honoring deities as kyrios/a in the Roman period does not single out the Near East (possibly for reasons of conservation), ${ }^{23}$ when compared to Egypt (following an enduring tradition) and Thracia (and surrounding areas). Secondly, a relatively small amount of documents is found in Anatolia, although the worshippers' submission is an unquestionable characteristic of the so-called confession texts. ${ }^{24}$ These general observations prompt further examination.

ambiguity, Versnel 1998, 72-95. Pleket is followed by Versnel 2011, 287, for henotheistic trends ("This divine absolutism in many respects imitates the model of the worldly autocracy so typical of Hellenistic kingship"), but not for the "oriental" influence (128-129).

20 One recent example, Van der Toorn et al. $1999^{2}$, s.v. Kyrios (D. Zeller, 492): "the designation kyrios for gods is mainly a non-Greek, oriental phenomenon from Hellenistic and Roman times".

21 Cf. L'DNY LMLK'STRT 'L HMN (“To my Lord, to Milkashtart, god of Hammon”), quoted by Bonnet 2015, 318 (TSSI III, 32).

22 It is one of the "nine characteristics of henotheistic religion" (the fifth one: "cultic worship, personal submission to the god") of Versnel 2011, 289-296.

23 The PHI Greek inscriptions database (http://epigraphy.packhum.org/) is not helpful for setting proportions because the term is frequently used in socio-political (patronage and emperors) and Christian contexts.

24 Two testimonies only: Petzl 1994, no. 68, 16 (Men kyrios of Tiamos), and 123, 2 (Apollo Lairbenos; it is not a formulaic designation though there are plenty of acclamatory epithets, see above n. 10). 


\section{Kyrios/a translates as Ba'al/Ba'alat or Adon in the Levant}

The majority of Near Eastern dedications addressing their deity as kyrios/a comes from Syro-Phoenician and Arabic regions: coastal Syria, the Anti Lebanon from Bekaa to Hermon, and further east on the Hauran plateau to Gerasa and Bosra on the south, and north to the Euphrates. In these regions, the more so in hinterlands, local traditions of numerous divine masters were vivid, and they were even perpetuated thanks to Hellenization, as brilliantly demonstrated by Glen Bowersock (1990).

Kyrios/ $a$ is a literal translation of Semitic divine appellations: $B a$ 'al and Adon for gods, Ba'alat for goddesses. Like in the Phoenician history of Philo of

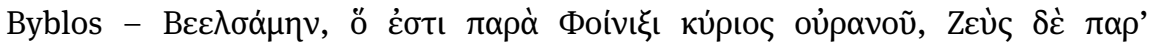
"E $\lambda \lambda \eta \sigma \iota v^{25}$ - the bilingual dedication of Seleucos (Bar'ateh in Palmyrenian), son of Lucius, leaves no doubt on the equivalence, though the use does not echo per se a specific religious experience of the god (PAT 1089). In $31 \mathrm{CE}-$ thus before Dura-Europos entered the imperium of Rome, though the presence of Rome is already perceptible in anthroponymy - Seleucos and his son Ababouis (bbwhy) of-

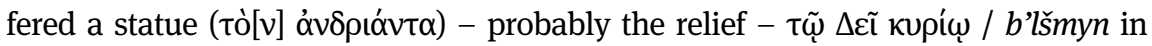
three "languages": Greek, Palmyrenian Aramaic, and iconographic (thanks to the sculptor / glyptès Iaraios / Yarhai). The document was found in a small structure (thus called "temple of Zeus kyrios") possibly erected c. 28 CE by immigrants coming from Palmyra. ${ }^{26}$ The inscription engraved on the plinth of the relief (Fig. 1) attests to the translation of the Aramaic Ba'al Shamîn as Zeus kyrios. There is only one other testimony in Dura: a Greek graffito dated to c. $210 \mathrm{CE}$, inscribed on a wall of one the rooms of the Roman praetorium that enclosed the temple of ArtemisAzzanathkona. ${ }^{27}$ It can be surmised that Aramaic was Seleucos' mother tongue, ${ }^{28}$ for he calls Ba'al Shamîn "lh", "my god" (with the suffix of ownership). This is a very thin clue for asserting a deep personal relationship of Seleucos with "his" god. Testimonies are more numerous in the Hauran, and that of Decimus Lucius Fabianus, a Roman legionary (legion unknown after the break of the stone) is more demonstrative for the point: he thanked "Zeus the Lord" for having been

25 Baumgarten 1981 ap. Eusebius, PE I, 10, 7 (= Jacoby, 790.F, 2, 46) and 149-152.

26 Downey 1977, 31-34 and 208-210, no. 10, pl. 4, fig. 10 (= LIMC 3, s.v. Zeus, 75-76 no. 1, pl. 62). Cf. Dirven 1999, 115-117 and 211-222 no. 5, pl. II and fig. 6 for the plan of the temple.

27 Rostovtzeff 1934, 161-162 no. 483.

28 On the complex Syrian "Greekness" in Dura, Andrade 2013, 211-232 (229-231 for the Seleucos monument). 


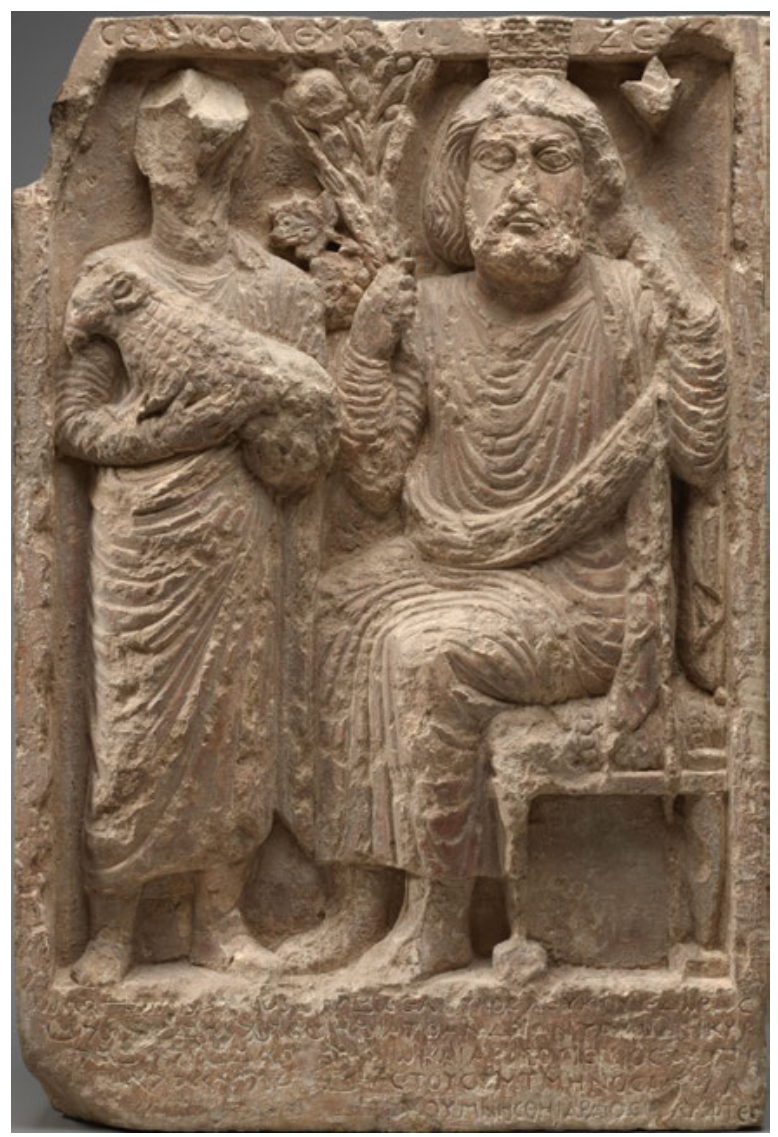

Fig. 1: Yale University Art Gallery, 1935.45 (https://artgallery.yale.edu/collections/objects/6833), public domain.

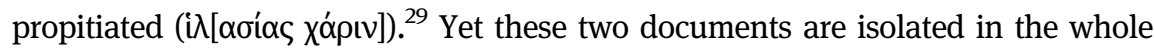
corpus analyzed below and cannot generate a systematic connection between the onomastic attribute and a specific religious experience.

Coming back to Seleucos in Dura, his relationship with Ba'al Shamîn in Aramaic (lh) is not paralleled in the Greek version of the dedication, nor in the relief. The latter pictures a commonplace sacrificial homage with Palmyrene iconographic features (Fig. 1). The god is seated, with his upper body facing the

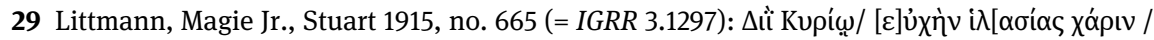

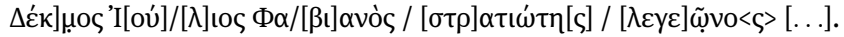


viewer but his legs on profile, wearing a calathos and holding a bunch of fruits and grains in his right hand. A man wearing a himation is standing on his right, probably an image of Seleucos bringing a ram as an offering (?). The depiction of a master god, provider of prosperity, expresses one of the providential features of the atmospheric Lord of the Heavens (Ba'al Shamîn).

The Greek translation might sound redundant, as the prominent status of local ba'alim ${ }^{30}$ was regularly interpreted in Greek by the master god Zeus' theonym, specified by an epichoric epithet (e.g. Zcù $\Delta \alpha \mu \alpha \sigma \kappa \varepsilon ́ v o \varsigma)$, when the

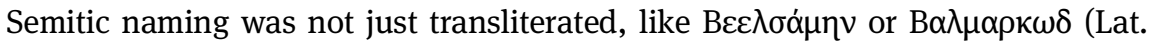
Balmarcod). Seleucos' Zeus kyrios version might intend to stress the mastership of the cult place, yet without any emphasis on a particular experience.

In the Hauran also (Sourdel 1952, 25-27), Zeus is honored as kyrios during the reign of the emperor Claudius. The area, then, was part of the land of the Herodian tetrarch Agrippa II, once it had been separated from the Nabatean sphere of influence half a century before. At Sanamein-Aire $(50 \mathrm{~km}$ south of Damascus), three brothers with local or Hellenized names (Eunomos son of

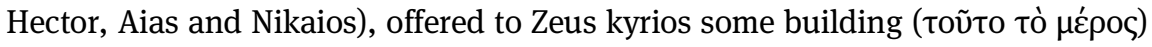

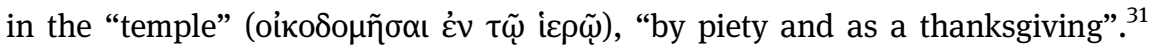
The temple is unlocated (unlike the Severian Tychaion, Dentzer-Feydi 2010). Yet the naming of the god as kyrios is consistent with the context of a cult place embellished or enlarged by the dedicants. The occasion for the dedication evokes regular religious homages, reinforced probably by euergetic concerns. The epithet of the god expresses in Greek a masterful position in his sanctuary, with no hint of specific experience of the god. One can read a similar semantic use in a consecration to a local ba'al (he is $\pi \alpha \tau \rho \tilde{\omega}$ oఢ) with a celestial field (he is oúpóvıoc) at Damas: ${ }^{32}$ once both his divine field and link with the dedicant have been designated, his status is explicitly stated ("the Lord" with article). In Bosra, the dedication of Gaius Iulius Maximus, a soldier of the IIIa legio Cyrenaica, "to Zeus kyrios and Hera, ancestral gods" ${ }^{33}$ points more probably towards a Roman context - Jupiter and Juno addressed with a local formula crossing a Jupiter dominus

30 Cf. PAT 1572, a bilingual dedication in Palmyra; in Gerasa a Zeus Kronos (Bel? Saturn?), SEG 7, 862. More generally Kaizer 2002, 83-84.

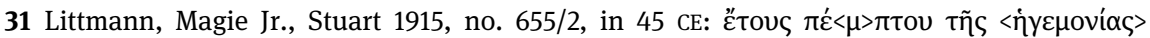

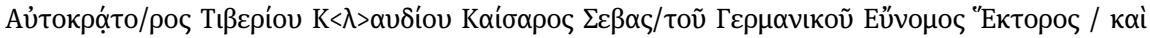

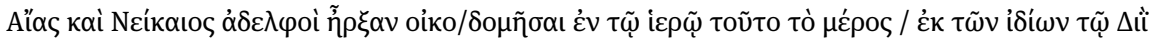

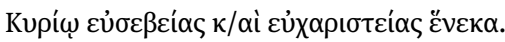

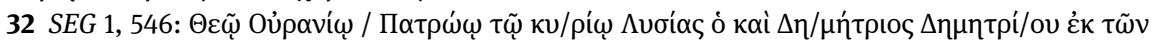

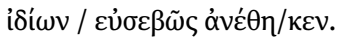

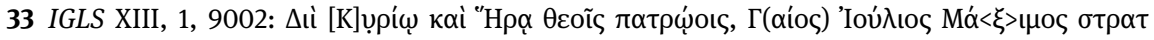

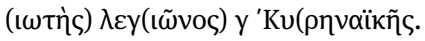


in Latin - than towards an interpretatio of local gods, for Hera did not match with local goddesses as far as I know. ${ }^{34}$

Such a crossing between two cultural traditions of master gods is widely illustrated at Berytus/Heliopolis, the more Roman of the Phoenician coastal cities, where every god with a public sanctuary is kyrios/a. In this Roman colony, there is a combination of an indigenous tradition - exemplified by the translit-

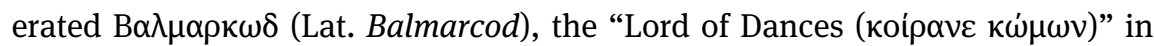
his sanctuary of Deir el Kala ${ }^{35}$ - with the colonial creation of Jupiter, Mercurius and Venus, for whom the Latin conception of dominus/a was vested with a welcomed local look. ${ }^{36}$ A late dedication (250-300 CE) “to Hermes Lord Savior” was engraved by worshippers with local or Hellenized names on the moulding of an altar adorned with a caduceus within a crown. ${ }^{37}$ The altar was found in the extra-urban sanctuary built on the Cheikh Abdallah hill (to the south of the colony), where a written boundary stone delimited Hermes' territory. ${ }^{38}$

A reverse bronze coin struck by Heliopolis under Philip the Arab (Fig. 2) pictures the temple on a rocky hill with a stepped path, with the purse and the caduceus in the field. Three Latin dedications found in the sanctuary call the god dominus. They were commissioned by well-known Berytan families (the Afidenii, Statilii and Tittii) and betray a Roman context in many respects: onomastics, nomenclatures, military functions and epigraphic formulas. ${ }^{39}$ The fact that a god is called kyrios in his cult place is an expected designation of his ownership status and crosses many testimonies of deities honored as dominus/a in Latin. In the colony of Berytus/Heliopolis, the majority of homages to Mercurius are in Latin. All (but two) are offered Mercurio domino, ${ }^{40}$ thus suggesting a

34 Pirenne Delforge and Pironti 2016 do not examine Roman evidence.

35 Cf. Rey-Coquais 1999, 626-627; Aliquot 2009a, 138-139; Belayche and Hošek 2011, 389-391.

36 Cf. Hošek 2017.

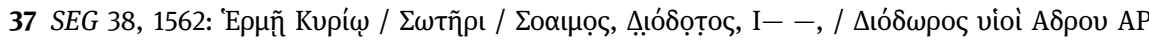
-- .

38 Cf. Aliquot 2009a, 294 for archaeological data, and 207-211. See also Aliquot 2009b.

39 IGLS VI, 2737: Mercuri/o Dom(ino) / L(ucius) Afidenus / Stati[li]a[nus] / Val[ens]; SalaméSarkis 1987, 130, no. 7: (Mercu[ri]/o do[m(ino)] / Tittia / Severa / Rufilli / [-]); 131 no. 8: Mercur[i]/o dom(ino) / Stat(ilius) Afide/nus L(uci) f(ilius) Fab(ia tribu) Ru/fillus, praefectus / fab[rum], tri(bunus) mil(itum) / leg(ionis) V Mac(edonicae) / v(otum) l(ibens) a(nimo) s(olvit).

40 Cf. $A E$ 1924, 1138 (Berytus): Mercurio / Domino / Q(uintus) Antonius / Eutyches / Sacerdotia/nus pro sal[u]/te sua et uxo/ris et filio[r(um)] / v(otum) l(ibens) a(nimo) s(olvit); $A E$ 2009, 1572 (Berytus): [Mer]curio Domin(o) / [e]x responso Apolli/nis C(aius) Iulius Her/mes Cinnamu[s] / geometra. Venus, who is the more Roman figure of the "triad" (see Hošek 2012, 402-409) is domina as well, AE 1924, 137 (= Triade I, no. 212): Veneri Dom(inae) / Caninia pr(o) s(alute) s(ua) / et Q(uinti) et fil(ii) Max(imi) / v(otum) l(ibens) a(nimo) s(olvit). 

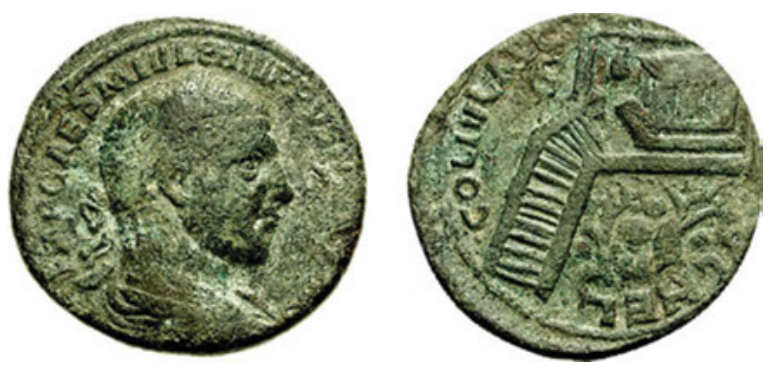

Fig. 2: SNG Copenhagen 435, Philip the Arab, used by courtesy of CNG, www.cngcoins.com.

formulaic designation with a Roman inspiration. ${ }^{41}$ This is confirmed by a dedication from a village which honors "Mercurius lord of the village of Ham (Mcркоupí $\omega$

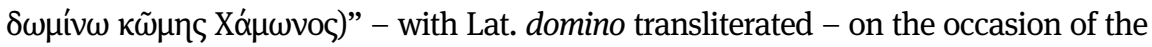
building of his temple. ${ }^{42}$ When comparing these testimonies to the one of Hermes kyrios, both express an authoritative status of the god, crossing two traditions, dominus and ba'al. Linguistic transfers were not one-way processes, whatever their apparent direction, and the building of the figure of Mercurius through his namings combines many features, both local and transferred ones, of the "tuf culturel", to speak with Louis Robert for Anatolia (Hošek 2012, 260-273).

With Jupiter and Venus, this Mercurius/Hermes was one of the three figures of the so-called "Heliopolitan triad", a modern reconstruction that recent researches invite rightly to dismiss. ${ }^{43}$ The religious identity of the Heliopolitan Mercurius raised many debates recently as well. Julien Aliquot studied the god's pre-Roman presence in Lebanon, for the caduceus is displayed on coins' reverses of the Iturean tetrarchs of Chalcis in the 1st century BCE. He emphasized Mercurius' quality of being a messenger, akin to the Palmyrenian Malakbel, which would have put a dominus/kyrios like him in a secondary rank (Aliquot 2009b), if the "triad” actually existed. Anne-Rose Hošek took to pieces the iconographic, cultural and religious bricolage that Roman colonists who built this divine figure manufactured; she underlines his aspect as a cosmic figure, far from the traditional image of being both a shepherd-god and secondary power (Hošek 2012, 389-401). For my concern with respect to the experience devotees had of gods they called "kyrios", it is important that the two male gods of the so-called triad, Jupiter and Mercurius, both "kyrios/dominus", are

41 Hošek 2012, 301-302. A similar phenomenon in Africa with Saturn, Le Glay 1966, 125.

42 Triade I, no. 168 (= Hošek 2012, 302).

43 Cf. Kropp 2010. For a close study of the debate, Hošek 2012, 430-474. 
often associated in reliefs and dedications (Hošek 2012, 391-393 and 414). Far from exhibiting inconsistency (Versnel 2017), they illustrate the conception of cohabitation of equally powerful divine powers within polytheism.

Heliopolitan Jupiter is dominus, rarely kyrios, because he is generally given homages in Latin. Thus the few dedications coming from Heliopolis and addressing him as kyrios or despotes offer helpful testimonies for discriminating between the two meanings and checking the "henotheistic" feature of kyrios if one follows the dominant scholarship. Under the Severans, Apollonios Segna, a citizen of Arados (further north on the coast), together with his children,

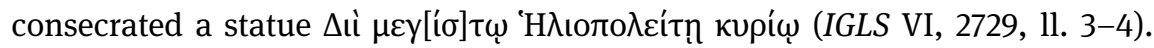
This worshipper reports a privileged relationship with the god through an ora-

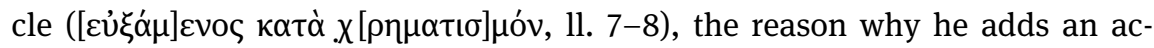
knowledgement of the god's powerful quality (megistos) to his authoritative status in his sanctuary (kyrios). For a couple of Roman citizens (Cassius Verus and Chareinè), worshippers of the Heliopolitan god (Jupiter probably), this allpowerful conception of the god of their homage is expressed by both megistos and despotes, ${ }^{44}$ two epithets that distance their special experience of the god from the more common formula dominus/kyrios. The two aforementioned Heliopolitan dedications throw light on the rhetorical means for testifying of a specific experience of the god. But there is no great evidence for relating them to an "oriental" tradition, which would have existed in Arados for instance. In the famous inscription of Baitokaeke, the great sanctuary of a local Zeus/Ba'al in the chora of Arados, ${ }^{45}$ the two emperors Valerian and Gratian (in 258-260) recalled economic and fiscal privileges for the sanctuary. The liberality is explicitly linked with the

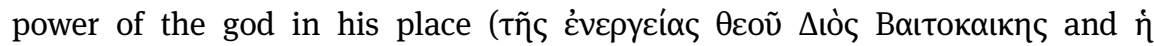

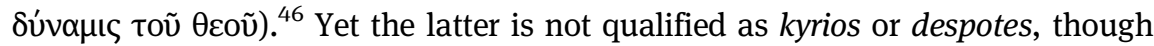
his power is duly underlined.

Local tradition is more likely expressed in Greek dedications offered to Kronos. At Nebi Abel, south-west of Abila, eleven worshippers offered an altar in 166/167 "to Kronos kyrios after an oracle of the gods Zeus and Apis of Abila". 47

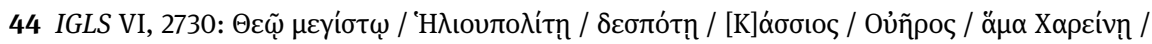

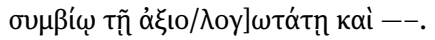

45 Cf. Darbbour and Tholbecq 2009. A general overview in Bonnet 2015, 138-142.

46 IGLS VII, 4028, C 18b-20 and Feissel 1993.

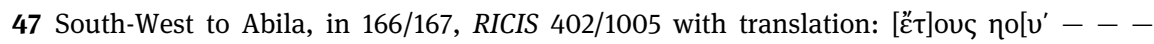

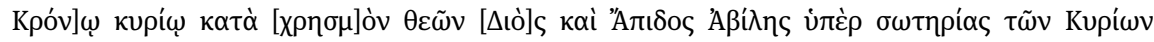

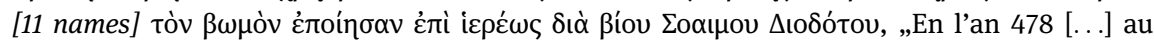
seigneur [Kron]os conformément à un oracle des dieux [Zeu]s et Apis d'Abila, pour le salut des Seigneurs [list of 11 names] ont fait l'autel sous le prêtre à vie Sahaimos fils de Diodotos“. 
The deity of the place, Kronos, is kyrios, while those of the religious experience are not. Thanks to another dedication cut on the rock between 14 and $29 \mathrm{CE}$, we know that his temple and the road access were offered by Nymphaios, son of Abimmes, an emancipated slave of the tetrarch Lysanias.

Pour le salut des Seigneurs augustes et toute leur maison, Nymphaios fils d'Abimmès, af-

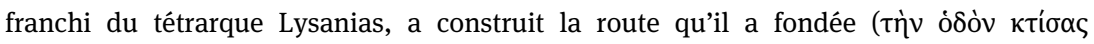

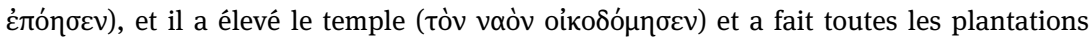

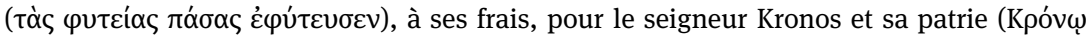

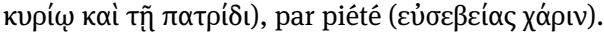

[OGIS 606; transl. Aliquot 2009a, 161, slightly modified]

In his dedication, Nymphaios links the divine owner of the newly founded cult place (Kronos kyrios) and the town related to him (his motherland). He does not report a specific religious experience besides the current piety and euergetism of this former slave. This Kronos kyrios recalls the Phoenician theology of Philo of Byblos, wherein Kronos is figured as the founder of the city of Byblos, the city being his house, i.e. temple, ${ }^{48}$ according to a long tradition, Mesopotamian and then Ugaritic. ${ }^{49}$ In that context, the "courtesy title" proposed by A.D. Nock is rightly consistent. In the Philonian mythology, woven with so many intricate cultural references, Kronos holds a prominent place as a primordial and founding figure, the one who dispatches the world between the deities, in the wake of the Hesiodic tradition. ${ }^{50}$ Byblos, a main concern for the author as his homeland, is given to Ba'alat Gubal, the Lady of Byblos (Bonnet 2015, 164-171), and Phoenicia to the couple Zeus and Hadad-Astarte. In evidence of the Roman period, there is only one document (as far as I know) displaying Kronos kyrios as a supreme and cosmic deity. At Maad, in the mountainous hinterland of Byblos, a group of inscriptions was found in a church built on the ruins of a pagan building. One dedication, still discussed, is engraved on a cippus within a tabula ansata:

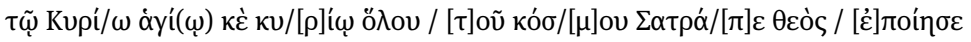

To the saint Lord and Lord of the whole universe, the god Satrapes made (this dedication). ${ }^{51}$

48 Baumgarten 1981 ap. Eusebius, PE I, 10, 19: "Following these events, Kronos builds a wall around his dwelling and founds the first city in Phoenicia, Byblos”. See Ribichini 1994.

49 Margueron 2016; Bonnet 2008.

50 Philo equates the Greek Kronos with the Ugaritic El (Baumgarten 1981, 180-213), though some of his deeds are parallel to those of the Greek Zeus.

51 Chausson and Nordiguian 1996, 40-43 no. 1, with French translation. 
The first lines configure an all-powerful deity, honored for his sanctity like many deities in the Near East: an imperial type Kyrios, who has parallels with the biblical Kyrios and in Isiac aretalogies anchored on Egyptian tradition. The god Satrapes ${ }^{52}$ is the Greek spelling of a Phoenician god Shadrafa, ${ }^{53}$ honored at Sarepta and known in Palmyra as well (see PAT 0206), a "dieu protecteur, apotropaïque et thérapeutique" (Bonnet 2015, 195). Actually, he is pictured at Palmyra in a military garment, but the spear he leans on is wrapped by a snake's coils, ${ }^{54}$ as in Asclepieian iconography. Both the garment and attribute suggest a cultural fertilization by Greco-Roman figuration. Leaving aside the question of dedications made by gods (Milik 1972) - a question that Ernest Renan, the first editor of the document, bypassed when reading an anthroponym "Etheos" on line $5-$, a divine power as universal ruler, and even further a local lordship regularly acknowledged by the title "kyrios", is not the rule so far. It is unique even at Maad.

A last example puts kyrios in a masterful position with no specific religious experience of him. In the mid-2nd century, at Skythopolis (Beth Shean) - one of the cities of the former Decapolis with a deep Hellenistic background -, Dionysos is kyrios and ktistes:

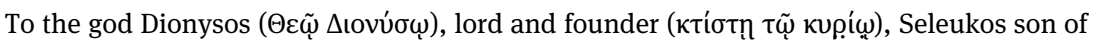

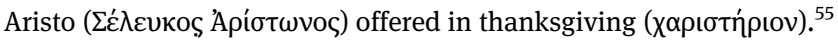

Though granted by scholarship with a prominent place in the local pantheon, Dionysos was not the only deity honored as kyrios there. He shares the epithet with Kore, kyria in her cult place at the foot of the theater (Fig. 3).

Yet Kore is far more glorified in Sebaste where she is "a mistress of every-

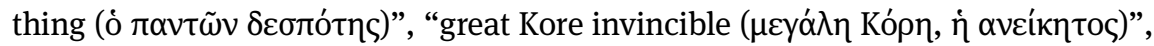

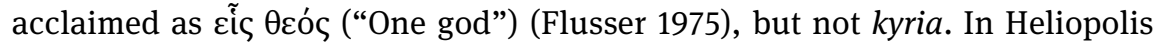
as well, Kronos is despotes (and not kyrios) for a group of religious servants

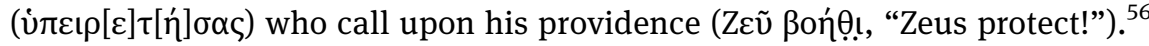

52 F. Chausson, who republished the text in 1996, chooses the reading on lines 5-6: Satrapes (nominative), with omission of the "s".

53 The theonym would be Iranian, meaning "The Lord of Power", Dupont-Sommer 1976, 653. At Maad in 8 BCE, he is honored by a local worshipper with no epiclesis, Chausson and Nordiguian 1996, 43 no. 2.

54 Cf. Drijvers 1976, pl. XL VIII; for the inscription PAT 0318. See also Gawlikowski 1990, 2646-2647.

55 Di Segni 1997. See Belayche 2017, 11-15.

56 IGLS VI, 2740 with translation: Zeṽ ßoń

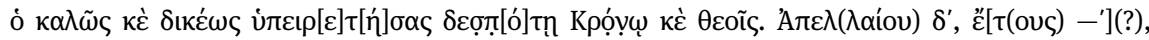
"Zeus protège ! Qu'on se souvienne de ceux de la $3^{\text {ème }}$ décanie. Martinos fils de Marinos ayant servi bien et justement le maître Cronos et les dieux, le 4 du mois Apellaios, en l'an [...]”. 


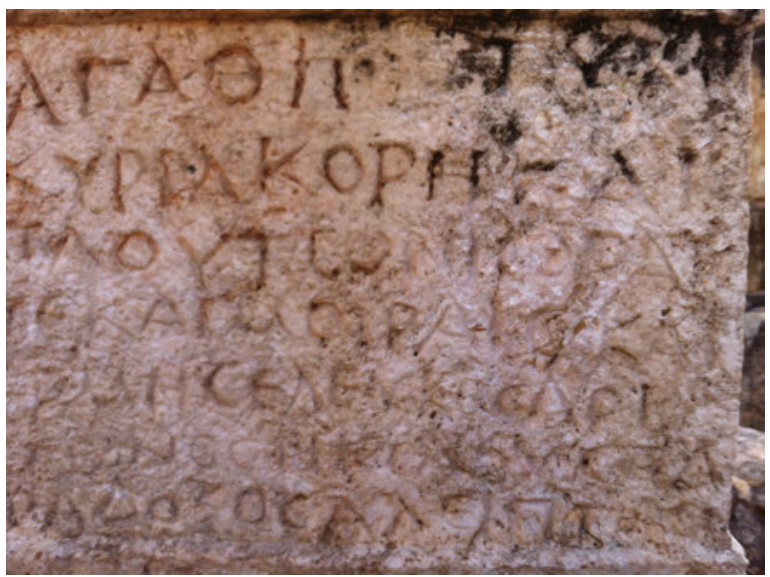

Fig. 3: Skythopolis, inscription in situ in the temple of Demeter and Kore (photo: N. Belayche).

Definitely kyrios points towards rulership of a place, temple or city, compared to despotes, which is more akin to expressing a special experience of the deity and of his/her supreme position.

Recalling the three features that dominant historiography considers as characteristic of the use of kyrios - personal submission, oriental influence and henotheistic conception - this review of Near Eastern attestations demonstrates firstly that kyrios is not a systematic formula for gods in the Near East. Secondly, it designates local rulership of a place, with rare cases of intimate religious experiences of the respective god. The conclusion is not different for goddesses called kyria in the Levant, though we do find more numerous mentions of a specific and personal experience of their divine power.

As for male gods, the Greek "courtesy title" (Nock) is a regular translation of Ba'alat ("Lady/Dame"). Testimonies of goddesses called "kyria" are concentrated on a few divine figures, ${ }^{57}$ because of the prevalence of the "Lady Astarte" in many Phoenician documents, ${ }^{58}$ either in her Syrian form (kyria Atargatis) or in her Greek interpretation (kyria Artemis). She is regularly portrayed on reverses of Levantine civic coinages because of the role she plays in civic protection,

57 Two examples: Athena, a Greek interpretatio of the Nabatean Allat, SEG 7, 1103 (Arabia,

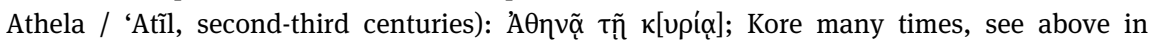
Skythopolis and IGLS VI, 2978 (Chalcis of Lebanon, 'Anğarr, second-third centuries): †ท̃ kupía Kópn.

58 See also Punic documents in the West, CIS I, 3914 (Carthage, fourth-third centuries BCE): "To the Ladies, to Astarte and to Tanit in Lebanon". 
comparable to the Tychai. In the Eastern Hermon at Kafr Hawar (to the south

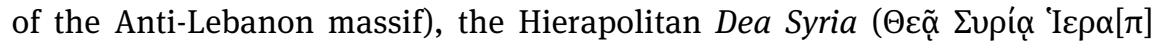

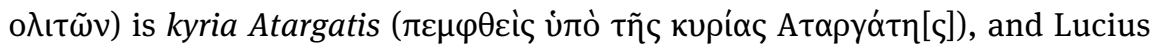

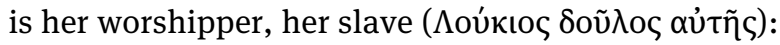

(A) : A la déesse syrienne de Hiérapolis, Lucius, son esclave, a consacré l'autel, étant venu 20 fois et ayant rempli 40 sacs.

(B) : Lucius d'Akraba, pieux et envoyé par la Maîtresse Atargatis,

(C) : a fait lui-même toute l'inscription sur l'autel grâce à 24 autres déplacements,

(D) : il a offert pour chaque déplacement 2 sacs [...].

[IGLS XI, 45, B 3-5 and A 1-4, transl. Aliquot 79]

This document might sound as a perfect case for the "orthodox" interpretation (Pleket). But it is unique among other attestations for Artemis kyria. Moreover, Lucius is a servant of the goddess, either a wandering priest (Aliquot 2009, 79) or charged with collecting the revenues of sacred lands; in both cases, the goddess is her "boss", her kyria. Obscure "Ladies of X place" are given the honor-

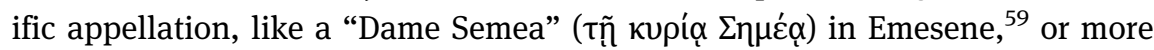
well-known figures, like those of the circle of Pan, the divine owner of the sanctuary of Caesarea Philippi/Banias (Southern Hermon): Nemesis (honored by a priest of Pan) ${ }^{60}$ and the Nymph Echo. Dedications to Nemesis do not stress any special relationship, in contrast to that of a statue of "Lady Echo ( $\tau \dot{\eta} v \kappa[u] \rho[i \alpha v]$

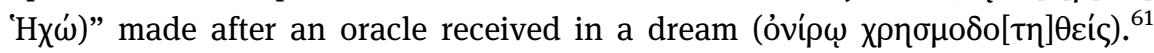
Two other monuments stress a personal relationship: in Gerasa where Artemis

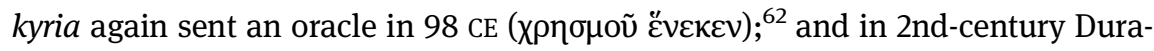

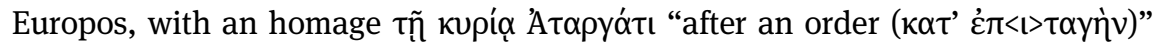
(SEG 7, 801).

Again, these few experiences are not in the majority for goddesses called kyria. Artemis in Gerasa (Djerash) is a good case because, within the context of her competition with Zeus, who settled for long at the gate of the city, his temple adjoining the theater, she was set in a prominent place in the urban grid

59 IGLS V, 2089, Burdj el-Qā‘I in 196/7.

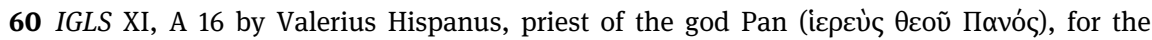

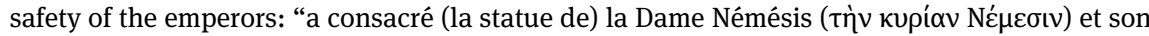
temple, achevé avec la roche creusée par lui-même, avec son décor et sa grille de fer tout entire” (transl. Aliquot); in Palmyra, Seyrig 1950, 242-247, no. 6, 1. 3 (Flavius Domitianus

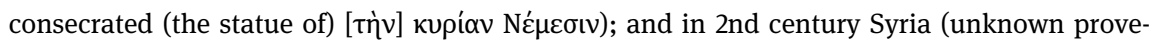
nance), Dain 1933, 92, no. 84.

61 IGLS XI, A 17, by Agrippa, son of Marcus, a magistrate, in 221/222.

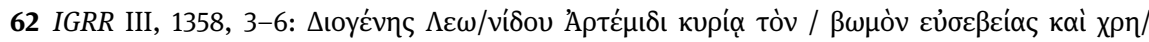

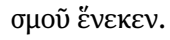


redesigned with the monumentalization of her temple under Antoninus Pius. She gets four dedications as kyria by both Hellenized natives and Romans, between the last quarter of the 1st century ${ }^{63}$ and the 2nd century, when she is praised by ritual agents ( $\dot{\alpha} \rho \chi\llcorner\omega \mu \iota \sigma \alpha i)$ of other gods (Apollo, Kore and sunnaoi theoi) as celestial Lady $^{64}$ - polytheistic thinking being consistent with cohabitations of divine powers. In 209-211, Flavius Munatius, bouleutes, paid for the mosaic pavement of the pronaos of her temple. ${ }^{65}$ The designation looks formulaic for the civic deity, like in Laodicea of Lebanon where she is similarly honored by two priestesses as well. ${ }^{66}$ Her naming as kyria underlines the importance of her sanctuary.

For both female and male deities, kyrios/ $a$ in the Levant is firstly the devotional recognition of a status of local, divine leadership. Expressions of specific religious experiences connected with this onomastic attribute are few and situational, and not a systematic feature. Thus the prevailing interpretative model of kyrios/a would need further argument to switch from describing occasional cases to an actual pattern. This conclusion is also supported by another region where deities of both genres are regularly honored as kyrios/a: Thracia.

\section{Kyrios/a as master of the local sanctuary in Thracia (and its surroundings)}

I shall review more quickly the area of the Lower Danube provinces, because testimonies are numerous indeed, yet laconic and repetitive. They demonstrate clearly, to my eyes, that kyrios/a is foremost the designation for the local divine master. Any deity, within any cultural tradition (indigenous and Greco-Romanized), within any context (villages, Greek cities, Roman colonies), is honored as kyrios/ $a$ with traditional ritual (vows and regular offerings) by devotees of any social rank (up to bouleutai). Besides the "Thracian Hero/Rider" 67 and various local

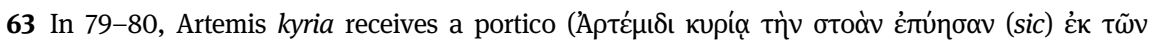

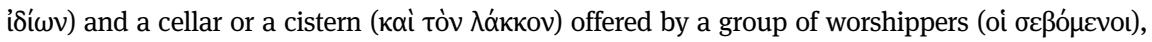
IGRR III, 1363.

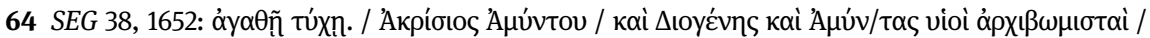

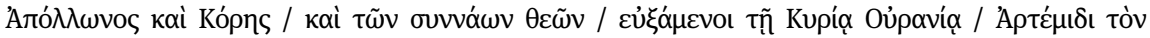

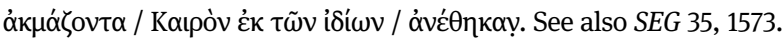

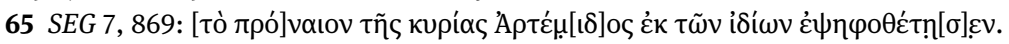

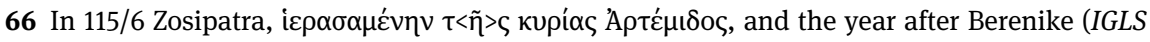
IV, 1263, 6-8, = RICIS 402/0302) and 1264).

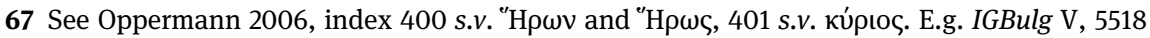

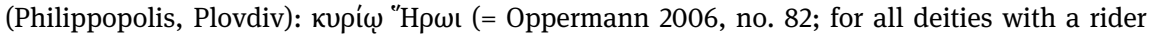


deities interpreted or not with Greek names and pictured or not as riders, ${ }^{68}$ all gods/goddesses with Greek names are kyrios/a: Zeus ${ }^{69}$ with Hera, ${ }^{70}$ Asclepios many times, ${ }^{71}$ Pluto, ${ }^{72}$ Dionysos, ${ }^{73}$ Sabazios, ${ }^{74}$ Ares, ${ }^{75}$ Apollo, ${ }^{76}$ Herakles, ${ }^{77}$ Artemis, ${ }^{78}$ the Nymphs, ${ }^{79}$ and so on. The honorific address fits to any divine figure, be it obscure for us like so many kyrioi of villages. ${ }^{80}$ Many dedications are made by soldiers, who were usually strangers to the province and probably adopted both a formulaic address and the iconography of the rider god that typify many of them. However numerous the instances, the title is rarely connected with a specific religious experience, e.g. salvation for soldiers, ${ }^{81}$ or oracular assistance, for instance by Lord Asclepios, Hygeia and Telesphoros (an interpretation of

relief and called kyrios in the territory of the city, 180-212); IGBulg IV, 2344 (Nicopolis ad

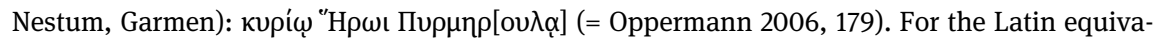
lent, dominus, Szabó 2017.

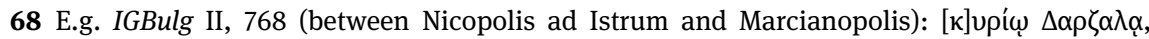
with a composite relief of a Greek-like, bearded god, sacrificing over an altar with a patera and holding the cornucopia (= Oppermann 2006, 292).

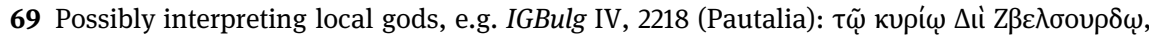

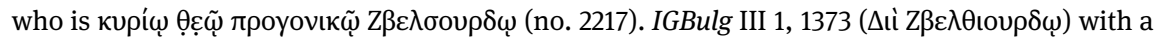
relief of Zeus with eagle and thunder.

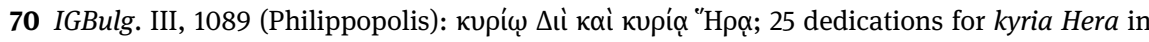
the IGBulg.

71 IGBulg V 5810: кupí $\omega$ 'A $\kappa \lambda \eta \pi ı[\tilde{\omega}]$, in Pautalia where there were curative springs and one (or

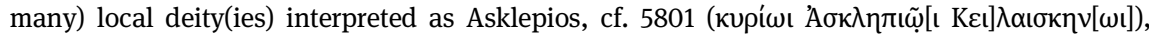

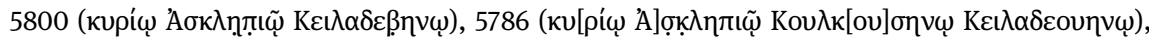

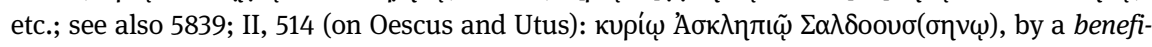
ciarius consularis in Greek, with a relief figuring Asclepios with Hygeia and Telesphoros. See Oppermann 2006, index 398-399.

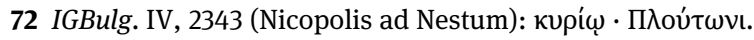

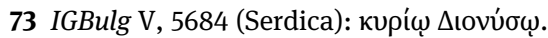

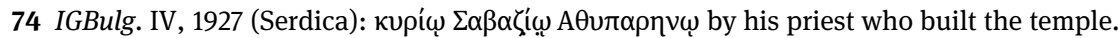

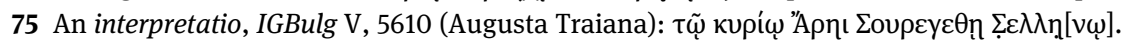

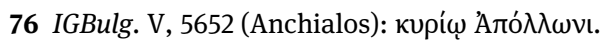

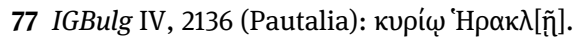

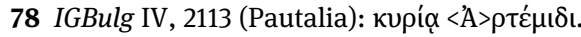

79 Seventeen dedications as kyriai in the IGBulg. Female deities (Hera, Artemis, the Nymphs, Hecate, etc.) are kyriai, yet with no systematic relief as the "Rider god". For Artemis figured as a huntress, Deoudi 2010.

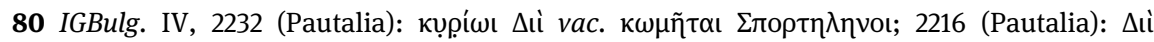

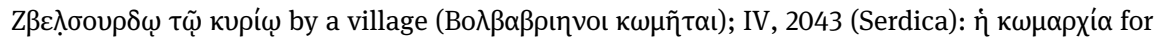
Lord Zeus; III, 1711 (Augusta Traiana): кирí 81 In Serdica, a soldier of the IIa legio Parthica thanks Lord Sabazios for his pronoia, IGBulg.

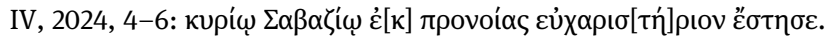




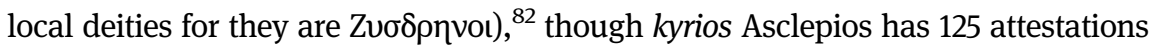
in the IGBulg. The onomastic attribute is a "courtesy title" that sets a status for divine powers. The term might have even looked much too formulaic for worshippers who were eager to single out their god or relate a special experience with him. In such cases, a further distinction needed to be added. In Pautalia the "Lord god Zbelsourdos" is praised as ancestral; ${ }^{83}$ in Serdica an Asclepios (probably an interpretation of a local/tribal? god) is kyrios and prostates; ${ }^{84}$ and in Apulum (Dacia) Lord Asclepios and Hygiea are singled out as epekooi (IGRR I, 541).

This brief, though representative, overview offers a clear picture of the meaning of kyrios when it qualifies deities in Thracia and its surroundings. As in the Near East, and without any clue for an influence though all testimonies date back to the Roman period, the designation is an expression of the status of the deity, as master in his sanctuary and thus patron of the community he or she protects. The fact that so many villages or peoples used the title is a convincing argument. If one searches for similarity with the Near Eastern ba'alim, it can be found in this relationship between a god in his "house"/temple and the people who lived nearby and expected a correlative protection. ${ }^{85}$ In that respect, the daily experience they had of the god might look like a privileged one, even without specific experiences like dreams or oracles. Yet the epigraphic repertoire proves that the special link between a god and his place and population became a formula expressing a status, and thus spread in any group, including newly settled populations like colonists and travelling soldiers. In these Low Danubian provinces, the many reliefs of the riding god (the so-called Thracian rider / Heros equitans $)^{86}$ might have been a way for investigating also the visual expression of a deity entitled as kyrios. They are inconclusive,

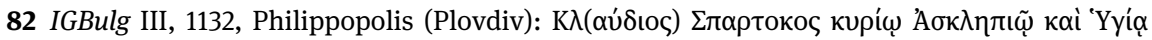

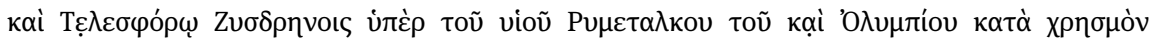

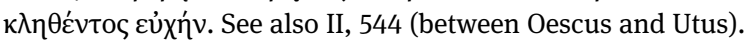

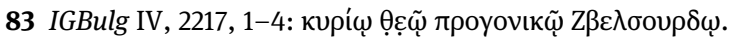

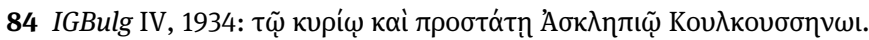

85 A parallel in Anatolian maledictions that entrust the integrity of the tomb to Kyria Anaeitis, cf. Herrmann 1962, 59 no. 54. Kyrioi theoi on gold leaves found in tombs at Egnatia (SEG 57, 923-924), and on lead tablets in the sanctuary of Demeter and Kore at Corinth (Stroud 2013, no. 127, 115-117).

86 Dimitrova 2002. The many attestations of gods honored as kyrios/a in Thracia led "thracologists" (gladly nationalistic) to a reconstruction of a Thracian pantheon dominated by an allpowerful solar deity in line with henotheistic reconstructions of religious evolutions during the imperial period; see for instance Tacheva-Hitova 1978. 
however, for the designation does not have a parallel in the iconographic language: the Heros equitans' motive stands for any deity, kyrios or not. ${ }^{87}$

\section{Kyrios and despotes in Roman Egypt}

The Egyptian dossier confirms what we observed in the case of Thracia. What is more important, it throws light on the distinction between kyrios and despotes with respect to religious experiences. As in the Lower Danube area, from the Nile Delta up to the Nubian desert ${ }^{88}$ almost all the gods are kyrios/ $a$ in their sanctuaries, whatever their rank of importance in the Egyptian divine world. At Pathyris (mod. Dabbabiyeh) in the western desert, a proskynema is offered in 232 CE to a "triad" of deities - among which an epichoric form of Isis ("who takes care of Egypt") - and to the "greatest gods" who share their temple. They

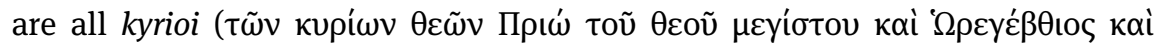

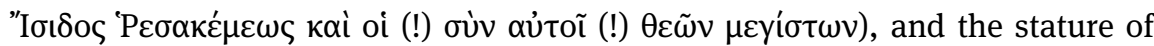
each is expressed either through their theonyms ${ }^{89}$ or through their distinction as megistos (greatest). ${ }^{90}$ The same precision occurs in Deir el-Bahari, where the

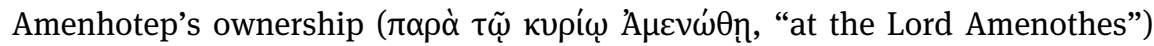

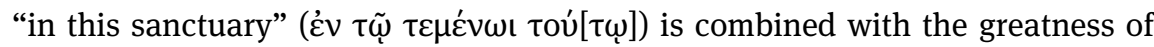

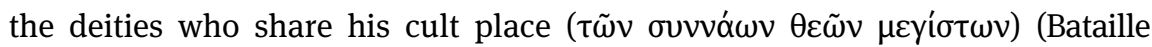
1951, 77). Whatever the deities' local or more universal stature, ${ }^{91}$ the designation as

87 I studied this dossier at the Chicago-Paris Workshop on Ancient Religions, "Image and Writing in Ancient Religions: Dispositifs, interactions, concurrence”, Paris 2016, September 19: "Image et écriture, interprétation et juxtaposition. Des reliefs adressés Kupí $\omega$ en Thrace romaine" (unpublished). The conclusion is not proper to kyrios, cf. Belayche 2008.

88 A few examples only among many from North to South: the god Sobek/Soukos (the god crocodile, Lord of the lake) at Soknopaiou Nesos (Dimai), in March 24 BCE, Bernand 1975, 73,

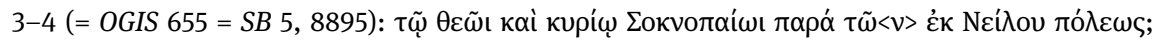

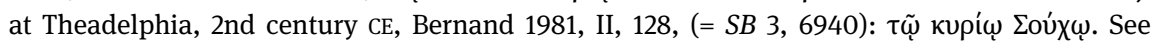

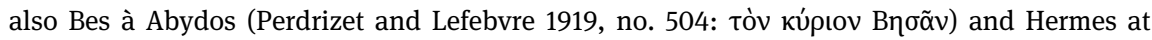
Pselkis (El Dakka), close to Kalabsha, in Nubia in 130/131 (IGRR I5, 1367 / $5092=$ SB 5, 7933):

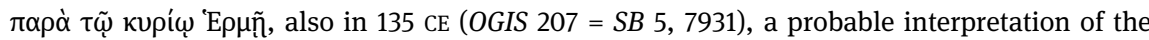
Egyptian god Thot, for he is honored by a physician (iatpós) of the XXa legio.

89 See Bricault and Pezin 1993, for their explication in Egyptian language.

90 Bernand 1989, no. 10 = IGRR I 5, 1271 = SB 1, 239.

91 Besides the expected Sarapis (SB 1, 1154 in the Fayoum) and Isis (Wagner 1987, 56 no. $10=$ SEG 30, 1723, at Kharga/Doush, a Western oasis, in 1st-2nd century), the god Pan in his Paneion at Wadi Hammamat honored by a Roman citizen in 14 BCE (IGRR I 5, $1235=S B 5$,

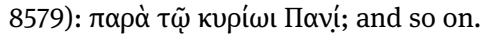


kyrios/a is but an expression of their status in the sanctuary, embedded within a social and polite rhetoric.

As already noted in Thracia, the addressee as kyrios is always attributed another quality when the devotee wishes to particularize the divine portrait or his/her experience. In the Memnonion of Abydos, the Osiris tomb housed an oracle, which was replaced by an oracle of Bes in the Roman period. ${ }^{92}$ The Memnonion housed a multitude of temples of gods and pharaohs (Seti I on the first rank); yet Bes is the only kyrios when he is honored with other deities. ${ }^{93}$ Silvanus son of Hermodoros rendered his homage in the sanctuary after a

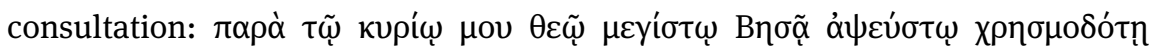
(Perdrizet and Lefebvre 1919, 505). He combines diverse devices for advertising

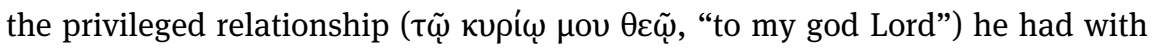
the god, and for expressing his exalted conception of him: Bes is megistos - another proof of the fact that kyrios does not cover the full register of glorifica-

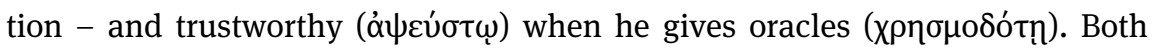
the context and experience of the deity recall Heliopolitan evidence (above p. 98), and the limits of the term kyrios for emphasizing a special relationship with a deity. This reading is confirmed in the temple of Hatshepsut at Deir elBahari (W of Thebes), where (Asclepios-) Amenothep (and Hygeia) had an incubation sanctuary. ${ }^{94}$ A well-known dipinto provides another proof. A rather detailed narrative of Athenodoros, a soldier garrisoned in Koptos under Hadrian (?), reports his nightly epiphanic experience of Asklepios, Amenothes and Hygeia: they are agathos (Asklepios and Amenothes), eudoxos (Amenothes), megistè (Hygeia), but not kyrios. ${ }^{95}$ In another 1st/2nd-century consultation, "Lord Amenothes" is praised

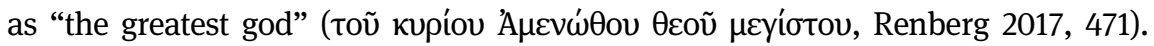
Similarly, in a 1st/2nd-century proskynema, Asclepios is praised as kyrios in the

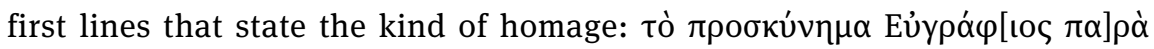

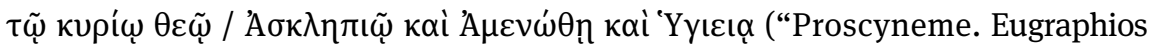
for the god Lord Asclepios, and Amenothes, and Hygeia”). Then when the text comes to the mention of the salutary experience, it opts for more accurate expressions of the divine absolute power and providential assistance: $\mu v \eta \dot{\sigma} \sigma \eta \tau \tau \dot{\eta} \mu \tilde{\omega} \nu$,

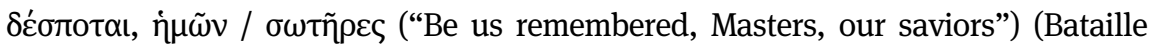
1951, 120). Despotes is the designation at this stage of the experience.

92 With incubation practices, Renberg 2017, 486-497, who does not examine addresses to the god.

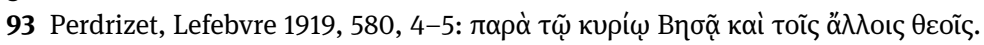

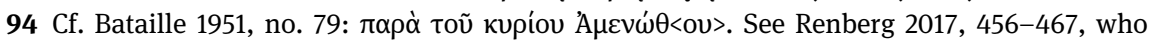
does not address the question of the appellation of the god.

95 Bataille 1951, no. 126; Renberg 2013. 
The distinction between the uses of kyrios and despotes for narrating specific religious experiences is clearer at Kalabsha/Talmis in Nubia (50 km to the south of the first Cataract). The Nubian god Mandoulis had a well-known oracular sanctuary in Roman Talmis, built under Augustus at a traditional meeting point of the nomadic tribes, with a cult place already. The place attracted a lot of pilgrims who left memories of their visits, in Greek language in the majority. Worshippers belonged to the surrounding population and to military units stationed in the south of Egypt up to the 3rd century. As expected, Mandoulis is kyrios in his sanctuary, ${ }^{96}$ and he is the only one so called when other deities are honored with him, like Bes at the Memnonion. When, under Vespasian, a Roman worshipper reports his homage made in the name of his whole family,

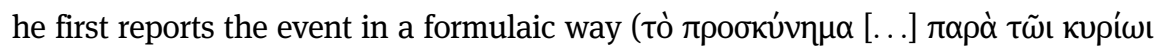

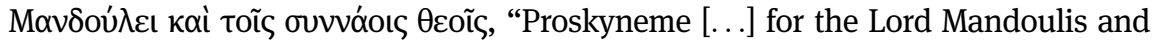
the deities who share his temple", ll. 1 \& 5-6). Then he details the motive of his

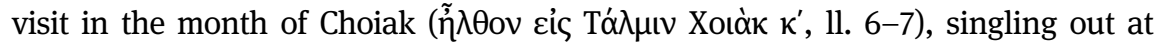

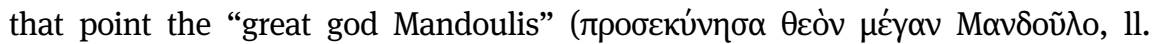

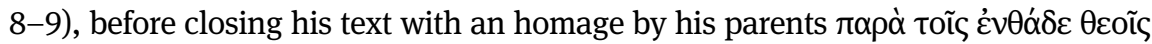
(1l. 9-10). ${ }^{97}$ The variations in the report of the proskynemata are instructive. There is a distinction of tone between the common statement of the first lines (kyrios) in most cases the only ones that were engraved by the pilgrims - and the more personal narrative that follows, where the god appears through his peculiar conception by his worshipper (megas, megistos in four other proskynemata written by Roman soldiers). ${ }^{98}$ An additional argument is offered by the famous poetic hymn to Mandoulis Aion, a very complex narrative of an epiphanic, religious experience, which deserves the numerous available studies. ${ }^{99}$ The purified, anonymous worshipper was granted a vision of a solar Mandoulis during a transforming experi-

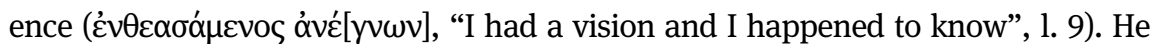

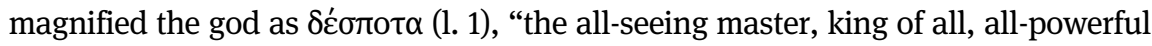

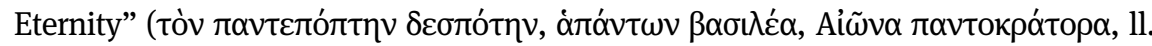
18-19). ${ }^{100}$ Although kyrios is formulaic in the sanctuary, it has no place in the flood of exalted designations accompanying a mystical-like experience.

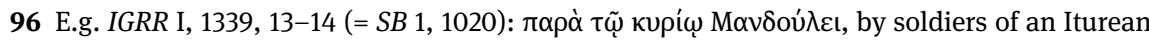
unit. See also 1346, and following.

97 Gauthier 1911-1914, 268, no. 1 = SB 1, 4586.

98 IGRR I 5, 1334 (= SB 1, 1018) and 1355 (= SB 5, 8532); Gauthier 1911-1914, 254 no. 14 (= SB 1, 4570) and 276 no. 18 (= SB 1, 4596).

99 Three references only: Nock 1934 [1972]; Frankfurter 1998, 108-109; Tallet 2012 (with exhaustive bibliography).

100 Bernand 1969, 166 (=SB 4127). 


\section{Conclusion}

Some conclusions can be asserted even if it has been impossible to take into account all testimonies within the length of a paper. Analysis of epigraphic evidence of deities called kyrios/a or despotes invites solidly founded reservations on the three features generally recognized when deities are praised as such (slave's submission, oriental flavor and henotheism). Any divine power is implicitly kyrios in his/her own sanctuary, as demonstrated in the three regions I focused on. This observation weakens an interpretation that would recognize a henotheistic trend when addresses with kyrios are found in dedications. Yet the title is not formulaic in all sanctuaries. For instance, Men Askaenos is not kyrios in his great sanctuary at Pisidian Antioch. In Pergamon Asclepios is rarely praised as kyrios, ${ }^{101}$ the more so never praised as such by his most beloved worshipper, Aelius Aristides, who is in a permanent, privileged relationship with him. Moreover, a deity called kyrios/a in a particular place is not systematically the great deity of that place. At Comana of Cappadocia, where the great temple of the goddess Ma (interpreted as Bellona by the Romans) was coextensive to the political power (up to its annexation), this Anatolian Mother, divine mistress of the temple-state, is not kyria. The divine powers praised with this title there are Apollo, Asclepios, Hermes and Men, in dedications offered by their priests, for whom their god is a Kyrios indeed. ${ }^{102}$ Kyrios is not a marker for preeminence in the representation of a pantheon. It is but a "courtesy title", a homage to a powerful figure, ${ }^{103}$ a "Monsignore". Gods are powers, thus they are all kyrioi as Paul said, and the term has no hyperbolic meaning that could characterize the henotheistic evolution of the imperial period. If the designation can match Near Eastern monarchic forms, it is not systematic for Levantine deities during the Roman period.

Inscriptions rarely show situations of submission, besides the basic fact that, in any religious relationship, there is always a gap between two imagined ontologies, the human and the divine one. In Thracia, dedications addressing deities as

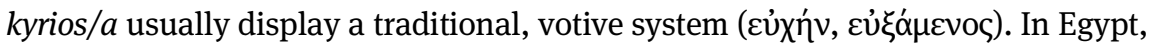
some attestations of deities honored as kyrios/a are read on proskynemata, a relevant corpus for "lived religion". And yet, in this Greco-Roman, Egyptian religious world, rooted in a long tradition of divine autocracy on the model of Pharaonic power, and where the gap between deities and humans was

101 IvP III, 106 (end of the 1st-beginning of the 2nd century), by a frumentarius of the legio VIa Ferrata.

102 Anatolian Studies 1972, 227-239, no. 2, 5, 6 and 10.

103 Versnel 2010, 279, speaks of a "superior title" in "prayers for justice". 
immeasurable for those who were not priests, ${ }^{104}$ addressing a deity as $k y r$ ios/ $a$ has a less personal impact than praising him/her as despotes. This could explain why despotes is more frequently used in poetic praises for deities, like in hymns honoring Isis. ${ }^{105}$ In that respect and depending on a chronological inquiry, despotes might be a better candidate for advocating an evolution towards a hierarchical/henotheistic conception of the pantheon and its expression in specific religious experiences.

\title{
Bibliography
}

\section{Abbreviations (for periodicals see L'Année philologique):}

\author{
ANRW: \\ Aufstieg und Niedergang der römischen Welt \\ CIS: \\ Corpus Inscriptionum Semiticarum \\ IDélos: \\ Inscriptions de Délos \\ IGBulg: \\ Inscriptiones Graecae in Bulgaria repertae \\ IGLS: \\ Inscriptions grecques et latines de Syrie \\ IGRR: \\ Inscriptiones Graecae ad Res Romanas pertinentes \\ IJO: \\ Inscriptiones Judaicae Orientis \\ ILeukopétra: \\ Ph.M. Photios, M.B. Hatzopoulos, L. Gounaropoulou, P. Paschidis 2000. \\ Inscriptions du sanctuaire de la Mère des Dieux autochthone de Leukopétra \\ (Macédoine). Meletemata 28. Athens. \\ IVP: $\quad$ Inschriften von Pergamon \\ LIMC: $\quad$ Lexicon Iconographicum Mythologiae Classicae \\ MAMA: $\quad$ Monumenta Asiae Minoris Antiqua \\ OGIS: $\quad$ Orientis Graeci Inscriptiones Selectae \\ PAT: \\ D.R. Hillers, E. Cussini 1996. Palmyrenian Aramaic Texts. Baltimore-London. \\ RICIS: \\ Recueil des inscriptions concernant les cultes isiaques \\ $S B:$ \\ Sammelbuch Griechischer Urkunden aus Ägypten \\ $S D B:$ \\ Supplément au Dictionnaire de la Bible
}

104 Like in Near Eastern temples, the topography of sanctuaries, with progressive areas (courts, then rooms) vested with different sacred qualities, up to the place where the divine figure stands (the naos or cella), opened only to ritual agents, gives a pertinent spatial image of the (im)possible contact with the "otherness".

105 Cf. the Isidoros hymn to Isis at Medinet Mādi (Narmouthis), Bernand 1969 no. 175, 24-26 (1st century BCE), with translation: “Mais les Egyptiens t’appellent $\Theta ı v ̃$ (l'unique), parce que tu es, toi seule / Toutes les déesses que les peuples nomment par d'autres noms. / Maîtresse

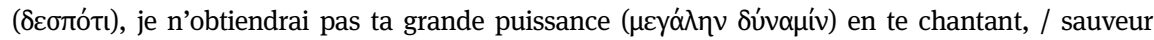

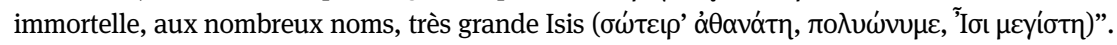


SEG:

Supplementum Epigraphicum Graecum

SNG: Sylloge Nummorum Graecorum

TAM:

Triade: Tituli Asiae Minoris

TWNT:

Y. Hajjar 1977. La triade d'Héliopolis-Baalbek, vol. 1-2. EPRO 59. Leiden. Theologisches Wörterbuch zum Neuen Testament

\section{Literature}

Aliquot, Julien 2009a. La vie religieuse au Liban sous l'Empire romain. BAH 189. Beirut.

Aliquot, Julien 2009b. „Mercure au Liban“, Topoi 16. 242-264.

Andrade, Nathanael J. 2013. Syrian Identity in the Greco-Roman World. Greek Culture in the Roman World. Cambridge.

Bataille, André 1951. Les inscriptions grecques du temple de Hatshepsout à Deir El-Bahari. Cairo.

Baudissin, Wolf W. von 1926-1929. Kyrios als Gottesname im Judentum und seine Stelle in der Religionsgeschichte. Giessen.

Baumgarten, Albert 1981. The Phoenician History of Philo of Byblos: A Commentary. EPRO 89. Leiden.

Bean, George E.; Mitford, Terence B. 1965. Journeys in Rough Cilicia in 1962 and 1963. ETAM 3. Vienna.

Belayche, Nicole 2000. «L'Oronte et le Tibre : L' 'Orient' des cultes 'orientaux' de l'empire romain. » In L'Orient dans l'histoire religieuse de l'Europe: L'invention des origines, ed. Mohammad A. Amir-Moezzi, John Scheid. BEHE/SR 110. Turnhout. 1-35.

Belayche, Nicole 2005. « 'Au(x) dieu(x) qui règne(nt) sur ...' Basileia divine et fonctionnement du polythéisme dans l'Anatolie impériale. » In Pouvoir et religion dans le monde romain: En hommage à Jean-Pierre Martin, ed. Annie Vigourt et al. Paris. 257-269.

Belayche, Nicole 2008. "Du texte à l'image: les reliefs sur les stèles 'de confession' d’Anatolie. »In Image et religions dans l'Antiquité gréco-romaine, ed. Sylvia Estienne, Dominique Jaillard, Claude Pouzadoux. Centre Jean Bérard 28. Naples. 181-194.

Belayche, Nicole 2010. "Deus deum ... summorum maximus (Apuleius): Ritual Expressions of Distinction in the Divine World in the Imperial Period." In One God: Studies in Pagan Monotheism and Related Religious Ideas in the Roman Empire, ed. Stephen Mitchell, Peter Van Nuffelen. Cambridge. 141-166.

Belayche, Nicole 2017. "Cults in Contexts in Hellenistic and Roman Southern Levant: The Challenge of Cult Places." In Expressions of Cult in the Southern Levant in the GrecoRoman Period. Manifestations in Text and Material Culture, ed. Oren Tal, Zeev Weiss. Contextualizing the Sacred 6. Turnhout. 3-21.

Belayche, Nicole et al. (eds) 2005. Nommer les dieux: Théonymes, épithètes, épiclèses dans l'Antiquité. Recherches sur les rhétoriques religieuses 5. Turnhout.

Belayche, Nicole; Hošek, Anne-Rose 2011. « Anatomie d'une rencontre dans des constructions volontaires: les colonies romaines de l'Orient romain. "In L'oiseau et le poisson: Cohabitations religieuses dans les mondes grec et romain, ed. Nicole Belayche, JeanDaniel Dubois. Religions dans l'histoire 6. Paris. 387-404.

Bernand, Etienne 1969. Inscriptions métriques de l'Égypte gréco-romaine: Recherches sur la poésie épigrammatique des Grecs en Égypte. Annales littéraires de l'Université de Besançon 98. Paris. 
Bernand, Etienne 1975. Recueil des inscriptions grecques du Fayoum. I, La 'Méris' d'Hérakleidès. Leiden.

Bernand, Etienne 1981. Recueil des inscriptions grecques du Fayoum. II, La 'Méris' de Thémistos. Paris.

Bernand, Etienne 1989. De Thèbes à Syène. Paris.

Bömer, Franz 1961. Untersuchungen über die Religion der Sklaven im Griechenland und Rom. III, Die wichtigsten Kulte griechischen Welt. Wiesbaden.

Bonnet, Corinne 2008. „Dove vivono gli dei? Note sulla terminologia fenicio-punica dei luoghi di culto e sui modi di rappresentazione del mondo divino." In Saturnia Tellus - Definizioni dello spazio consacrato in ambiente etrusco, italico, fenicio-punico, iberico e celtico, ed. Xavier Duprè Raventos, Sergio Ribichini, Stéphane Verger. Rome. 673-686.

Bonnet, Corinne 2015. Les enfants de Cadmos: Le paysage religieux de la Phénicie hellénistique. Paris.

Bonnet, Corinne et al. (eds) 2017. Puissances divines à l'épreuve du comparatisme: Constructions, variations et réseaux relationnels. BEHE/SR 175. Turnhout.

Bonnet, Corinne et al. (eds) 2018. "'Les dénominations des dieux nous offrent comme autant d'images dessinées' (Julien, Lettres 89b, 291 b). Repenser le binôme théonyme-épithète», Studi e Materiale di storia delle Religioni 84/2. 567-591.

Bousset, Wilhelm 1913. Kyrios Christos: Geschichte des Christusglaubens von den Anfängen des Christentums bis Irenaeus. Göttingen.

Bowersock, Glen W. 1990. Hellenism in Late Antiquity. Ann Arbor.

Bricault, Laurent; Pezin, Michel 1993. “Une nouvelle 'triade' pathyrite”, Bulletin de l'Institut français d'Archéologie Orientale 93. 67-77.

Bruchmann, Carl F.H. 1893-1902. Ausführliches Lexikon der griechischen und römischen Mythologie, ed. Wilhelm H. Roscher, suppl. VII. Epitheta deorum quae apud poetas graecos leguntur (and latinos). Leipzig.

Cerfaux, Louis 1931. "Le nom divin 'Kyrios' dans la Bible grecque ", Revue des sciences philosophiques et théologiques 20. 27-51.

Chaniotis, Angelos 2009. "The Dynamics of Rituals in the Roman Empire." In Ritual Dynamics and Religious Change in the Roman Empire. Proceedings of the Eighth Workshop of the International Network Impact of Empire, ed. Olivier Hekster, Sebastian Schmidt-Hofner, Christian Witschel. Impact of Empire 9. Leiden. 1-29.

Chaniotis, Angelos 2010. "Megatheism: The Search for the Almighty God and the Competition of Cults." In One God. Pagan Monotheism in the Roman Empire, ed. Stephen Mitchell, Peter Van Nuffelen. Cambridge. 112-140.

Chaniotis, Angelos; Chiai, Gian Franco 2007. „Die Sprache der religiösen Kommunikation im römischen Osten: Konvergenz und Differenzierung.“ In Antike Religionsgeschichte im raümlicher Perspektive, ed. Jörg Rüpke. Tübingen. 117-124.

Chantraine, Pierre [1968-1980] 2009. Dictionnaire étymologique de la langue grecque. Paris.

Chausson, François; Nordiguian, Levon 1996. "L'église de Maad et ses inscriptions », Syria 73. 37-46.

Chiekova, Dobrinka 2008. Cultes et vie religieuse des cités grecques du Pont gauche $\left(\mathrm{VII}^{e}-\mathrm{I}^{\text {er }}\right.$ siècles avant J.-C.). Bern.

Dain, Alphonse 1933. Inscriptions grecques du Musée du Louvre. Paris.

Darbbour, Yamen; Tholbecq, Laurent 2009. «Le sanctuaire de Baetocaecé (Hosn Suleiman, Jabal Al-Saheliyé, Syrie). Un état des lieux », Topoi 16. 207-223. 
Delplace, Christiane; Yon, Jean-Baptiste 2005. "Les inscriptions de l'Agora. » In L'Agora de Palmyre: sur la base des travaux de Henri Seyrig, Raymond Duru et Edmond Frézouls, ed. Christiane Delplace, Jacqueline Dentzer-Feydy. Bibliothèque archéologique et historique 175. Bordeaux-Beirut. 1-254.

Dentzer-Feydi, Jacqueline 2010. « Les sanctuaires païens de type régional en Syrie du sud. » In Hauran V. La Syrie du sud du Néolithique à l'Antiquité tardive. Recherches récentes, ed. Michel Al-Maqdissi, Frank Braemer, Jean-Marie Dentzer. Bibliothèque archéologique et historique 191. Beirut. 225-238.

Deoudi, Maria 2010. Die thrakische Jägerin: Römische Steindenkmäler aus Macedonia und Thracia. Wiesbaden.

Dimitrova, Nora 2002. "Inscriptions and Iconography in the Monuments of the Thracian Rider”, Hesperia 71. 209-229.

Dirven, Lucinda 1999. The Palmyrenes of Dura-Europos: A Study of Religious Interaction in Roman Syria. RGRW 138. Leiden.

Di Segni, Leah 1997. "A Dated Inscription from Beth Shean and the Cult of Dionysos Ktistes in Roman Scythopolis”, SCI 16. 139-161.

Downey, Suzan B. 1977. The Excavations at Dura-Europos: Final Report III, 2. The Stone and Plastic Sculptures. Los Angeles.

Drijvers, Hendrik J.W. 1976. The Religion of Palmyra. Iconography of Religions 15. Leiden.

Dupont-Sommer, André 1976. "L'énigme du dieu 'Satrape' et le dieu Mithra », CRAl 120.4. 648-660.

Feissel, Denis 1993. « Les privilèges de Baitokaiké: Remarques sur le rescrit de Valérien et le colophon du dossier », Syria 70.13-26.

Flusser, David 1975. “The Great Goddess of Samaria”, IEJ 25. 13-20.

Frankfurter, David 1998. Religion in Roman Egypt: Assimilation and Resistance. Princeton.

Gawlikowski, Michael 1990. "Les dieux de Palmyre », ANRW II.18.4. 2605-2658.

Harl, Marguerite (ed.) 1986. La Bible d'Alexandrie. 1. La genèse. Paris.

Herrmann, Peter 1962. Ergebnisse einer Reise in Nordostlydien. ÖAW, PhilosophischHistorische Klasse Denkschriften 80. Vienna.

Hošek, Anne-Rose 2012. Territoires et religions en contact: La colonie romaine de Berytus, de sa fondation au III siècle de notre ère. PhD EPHE Paris. https://hal.archives-ouvertes.fr/ tel-01552363/document.

Hošek, Anne-Rose 2017. " De Berytus à Héliopolis: nouvelles identités et recompositions territoriales. "In L'héritage grec des colonies romaines d'Orient: Interactions culturelles dans les provinces hellénophones de l'empire romain, ed. Cédric Brélaz. Paris. 311-330.

Kaizer, Ted 2002. The Religious Life of Palmyra. A Study of the Social Patterns of Worship in the Roman Period. Oriens et Occidens 4. Stuttgart.

Kropp, Andreas J.M. 2010. “Jupiter, Venus and Mercury of Heliopolis (Baalbek): The Images of the 'Triad' and Its Alleged Syncretisms", Syria 87. 229-264.

Lhote, Éric 2006. Les lamelles oraculaires de Dodone. Genève.

Littmann, Enno; Magie Jr., David; Stuart, Duane R. (eds) 1915. Syria. Publications of the Princeton University Archaeological Expeditions to Syria in 1904-1905 and 1909. III. Greek and Latin inscriptions in Syria. A 5, Haurân Plain and Djebel Haurân. London-Oxford.

Margueron, Jean-Claude 2016. « Entre profane et sacré: Y a-t-il des degrés dans la sacralisation de l'espace mésopotamien (IV e $^{\text {er }}$ millénaire av. J.-C.)? » In Espaces sacrés dans la Méditerranée antique, ed. Yves Lafond, Vincent Michel. Poitiers. 15-56. 
Milik, Joseph T. 1972. Dédicaces faites par des dieux (Palmyre, Hatra, Tyr) et des thiases sémitiques à l'époque romaine. Bibliothèque archéologique et historique 92. Beirut.

Nock, Arthur D. [1972] 1925. "Studies in the Graeco-Roman Beliefs of the Empire", JHS 45. 84-101 [= Essays on Religion and the Ancient World. Oxford. 33-48].

Nock, Arthur D. [1972] 1928. "Early Gentile Christianity and its Hellenistic Background." In Essays on the Trinity and the Incarnation, ed. Alfred E.J. Rawlinson. Oxford. 51-156. [= Essays on Religion and the Ancient World. Oxford. 49-133]

Nock, Arthur D. [1972] 1934. "A Vision of Mandoulis Aion", HThR 27. 53-104 [= Essays on Religion and the Ancient World. Oxford. 357-400].

Oppermann, Manfred 2006. Der thrakische Reiter des Ostbalkanraumes im Spannungsfeld von Graecitas, Romanitas und lokalen Traditionen. Langenweissbach.

Perdrizet, Paul; Lefebvre, Georges 1919. Les Graffites grecs du Memnonion d'Abydos. Nancy-Paris-Strasbourg.

Petzl, Georg 1994. Die Beichtinschriften Westkleinasiens. EA 22. Bonn.

Pietersma, Albert 1984. "Kyrios or Tetragram: A Renewed Quest for the Original LXX." In DE SEPTUAGINTA. Studies in Honour of J.W. Wevers on his Sixty-Fifth Birthday, ed. Albert Pietersma, Claude Cox. Mississauga. 85-101.

Pirenne Delforge, Vinciane; Pironti, Gabriella 2016. L'Héra de Zeus. Ennemie intime, épouse définitive. Paris.

Pleket, Henri W. 1981. "Religious History as the History of Mentality: The 'Believer’ as Servant of the Deity in the Greek World." In Faith, Hope and Worship. Aspects of Religious Mentality in the Ancient World, ed. Hendrik S. Versnel. Leiden. 152-192.

Renberg, Gil H. 2013. "The Athenodoros Dipinto Reconsidered (I.Deir el-Bahari 208)", ZPE 184. 103-115.

Renberg, Gil H. 2017. Where Dreams May Come: Incubation Sanctuaries in the Greco-Roman World. EPRO 184. Leiden.

Rey-Coquais, Jean-Paul 1999. «Deir el Qalaa », Topoi 9.2. 607-628.

Ribichini, Sergio 1994. "Le origine della città santa: Biblo nei miti della tradizione classica. » In Biblo: Una città e la sua cultura, ed. Enrico Acquaro et al. Rome. 215-230.

Ronchi, Giulia 1974-1977. Lexicon theonymon rerumque sacrarum et divinarum ad Aegyptum pertinentium quae in papyris ostracis titulis graecis latinisque in Aegypto repertis laudantur. Milan.

Rostovtzeff, Mikhail I. 1934. The Excavations at Dura-Europos: Preliminary Report of Fifth Season of Work, October 1931-March 1932. New Haven.

Salamé-Sarkis, Hassan 1987. "Heliopolitana monumenta”, Berytus 35. 126-139.

Santoro, Marcella 1974. Epitheta deorum in Asia graeca cultorum ex auctoribus graecis et latinis. Testi e documenti per lo studio dell'antichità 44. Milan.

Seyrig, Henri 1950. « Antiquités syriennes », Syria 27. 229-252.

Sourdel, Dominique 1952. Les cultes du Hauran à l'époque romaine. Paris.

Stroud, Ronald S. 2013. The Sanctuary of Demeter and Kore: The Inscriptions. Corinth XVIII.6. Princeton.

Szabó, Á. 2017. Domna et Domnus: Contributions to the Cult-History of the 'Danubian Riders' Religion. Vienna.

Tacheva-Hitova, Margarita 1978. „Über die Götterepitheta in den griechischen Inschriften aus Moesia Inferior und Thracia“, Bulgarian Historian Review 3. 52-65.

Tallet, Gaëlle 2012. «Interpréter les signes du dieu: Une apparition de Mandoulis au temple de Kalabchah. » In La raison des signes: Langages divinatoires, rites, signes et destin 
dans les sociétés de la Méditerranée ancienne, ed. Stella Georgoudi, Renée Koch Piettre, Francis Schmidt. RGRW 174. Leiden. 343-383.

Van der Toorn, Karel; Becking, Bob; van der Horst, Pieter W. (eds) 1999. Dictionary of Deities and Demons in the Bible. Leiden.

Versnel, Hendrik S. 1998. Inconsistencies in Greek and Roman Religion. I. Ter Unus. Isis, Dionysos, Hermes. Three Studies on Henotheism. Leiden.

Versnel, Hendrik S. 2010. "Prayers for Justice in East and West: Recent Finds and Publications." In Magical Practice in the Latin West, ed. Richard L. Gordon, Francisco Marco Simon. RGRW 168. Leiden. 275-354.

Versnel, Hendrik S. 2011. Coping with the Gods: Wayward Readings in Greek Theology. RGRW 173. Leiden.

Versnel, Hendrik S. 2017. «Polytheism and Omnipotence: Incompatible? » In Puissances divines à l'épreuve du comparatisme: constructions, variations et réseaux relationnels, ed. Corinne Bonnet et al. BEHE/SR 175. Turnhout. 255-275.

Veyne, Paul 1986. "Une évolution du paganisme gréco-romain : Injustice et piété des dieux, leurs ordres ou 'oracles' ", Latomus 45. 259-283.

Wagner, Guy 1987. Les Oasis d'Égypte à l'époque grecque, romaine et byzantine d'après les documents grecs (recherches de papyrologie et d'épigraphie grecques). IFAO. Paris. 
